\title{
A NEW CONTRIBUTION TO TRECENTO PAINTING AT STROSSMAYER GALLERY IN ZAGREB
}

\author{
Ljerka Dulibić, Iva Pasini Tržec
}

\author{
Lj. Dulibić \\ I. Pasini Tržec \\ Strossmayer Gallery of Old Masters \\ Croatian Academy of Sciences and Arts \\ ldulibic@hazu.hr \\ ipasini@hazu.hr
}

\begin{abstract}
In honour of Igor Fiskovic, the authors of the article re-consider a small but noteworthy group of Italian $14^{\text {th }}$ century paintings at the Strossmayer Gallery: Crucifixion (fragment) from the Circle of Bernardo Daddi, Temptation of Saint Anthony the Abbot by Niccolo di Pietro Gerini, Saint Nicholas with Donors and Angels by Maestro di San Martino a Mensola and Saint Francis of Assisi by Lorenzo di Bicci, which had been previously presented at the $9^{\text {th }}$ Days of Cvito Fiskovic, based mostly on critical analyses of relevant literature. Now, through the prism of new research into the provenance of the works of art, the authors sought to show the variety of ways in which not only rich historiography but also the vivid afterlives of four Trecento paintings obtained for the Strossmayer Gallery in different periods and under different circumstances, as well as fortuna critica and the fate of their counterparts, reflect the changes in the perception and the reception of Trecento painting in the second half of the $19^{\text {th }}$ Century and throughout the $20^{\text {th }}$ Century.
\end{abstract}

Keywords: The Strossmayer Gallery of Old Masters, Italian Trecento painting, Bernardo Daddi, Niccolo di Pietro Gerini, Maestro di San Martino a Mensola, Lorenzo di Bicci, Kunsthandlung Julius Böhler, provenance research, history of collecting

Some new findings based mostly on critical analyses of relevant literature on a small, but noteworthy, group of Italian $14^{\text {th }}$ century paintings at the Strossmayer Gallery, have been presented at the $9^{\text {th }}$ Days of Cvito Fisković in 2005. ${ }^{1}$ In the meantime, two of the paintings from this group have been restored, ${ }^{2}$ a proposal for partial reconstruction of predella to which one of the paintings belonged has been suggested in a detailed study and confirmed in a later publication. ${ }^{3}$ The research on the paintings presented in 2005 continues to this day, and is guided by new methodological aspects. ${ }^{4}$ In

\footnotetext{
${ }^{1}$ LJ. DULIBIĆ, Talijanske slike 14. stoljeća u zbirci Strossmayerove galerije starih majstora [Italian paintings from the $14^{\text {th }}$ century in the Strossmayer Gallery of Old Masters], (unpublished) conference paper at the $9^{\text {th }}$ Days of Cvito Fisković - Umjetnost i kultura 14. st. u Hrvatskoj [Art and Culture of the 14 $4^{\text {th }}$ Century in Croatia], 2005.

${ }^{2}$ Both paintings have been restored at the Croatian Conservation Institute, under the supervision of Nelka Bakliža: Saint Francis of Assisi by Lorenzo di Bicci in 2010/11, and the Temptation of Saint Anthony the Abbot by Niccolò di Pietro Gerini in 2013.

${ }^{3}$ LJ. DULIBIĆ, Predela "Iskušenje svetoga Antuna Pustinjaka" Niccolòa di Pietra Gerinija u Strossmayerovoj galeriji u Zagrebu [The Temptation of Saint Anthony the Abbot at the Strossmayer Gallery in Zagreb], in Radovi Instituta za povijest umjetnosti 30, Zagreb, 2006, p. 131-140; L. KANTER, „Niccolò di Pietro Gerini, The Martyrdom of Saint Lawrence", in Italian paintings from the Richard L. Feigen Collection, L. KANTER, J. MARCIARI (ed.), New HavenLondon, 2010, p. 36-38.

${ }^{4}$ Cfr. I. PASINI TRŽEC, LJ. DULIBIĆ, Un frammento "delle Marche disperse" nella Galleria Strossmayer di Zagabria, in Il capitale culturale. Studies on the Value of Cultural Heritage 10, Macerata, 2014, p. 135-156.
} 


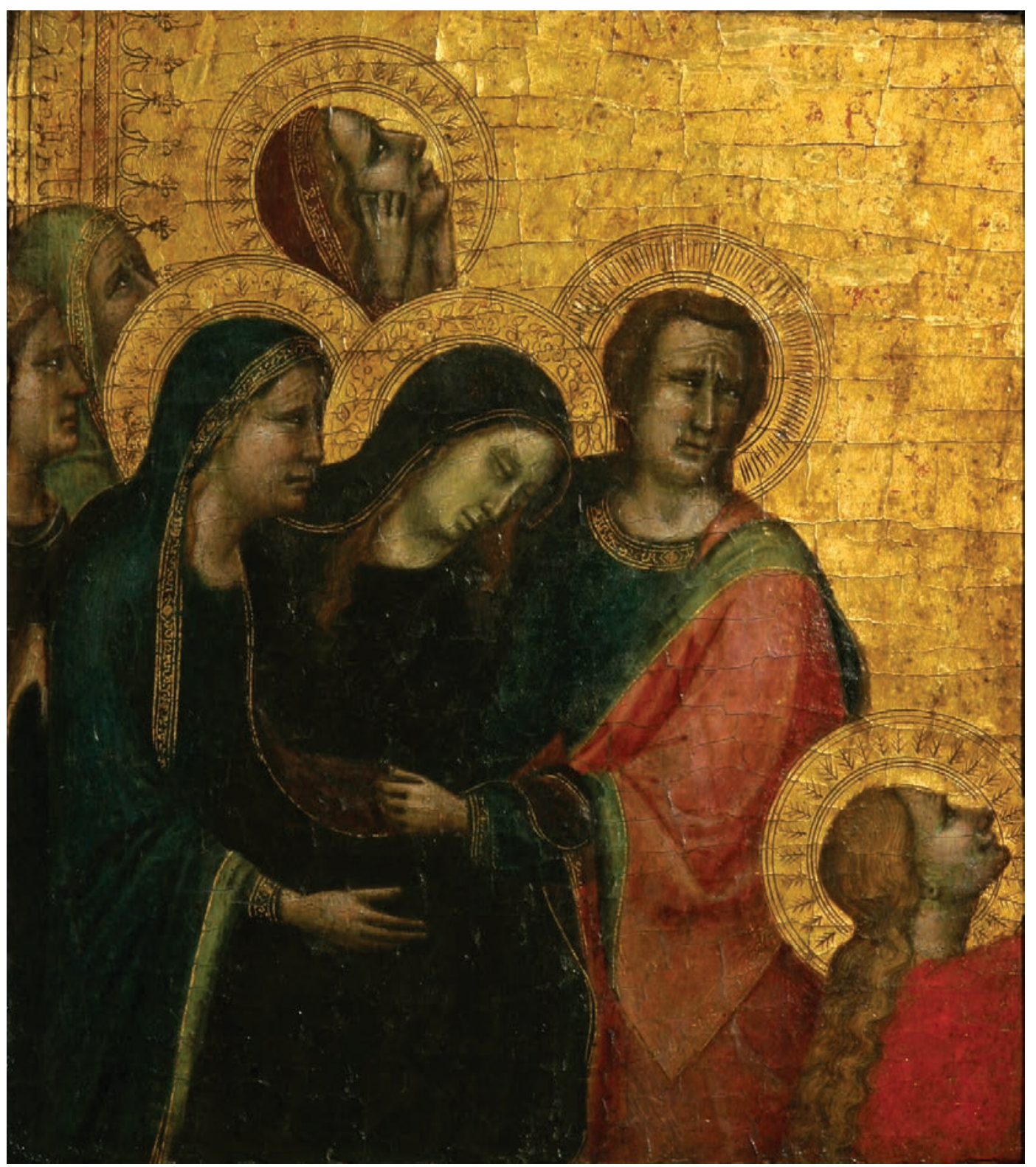

Fig. 1. Circle of Bernardo Daddi, Crucifixion (fragment), tempera on panel, 22,5 $\times 21 \mathrm{~cm}$, The Strossmayer Gallery of Old Masters HAZU, inv. no. SG-23.

honour of Igor Fisković, we decided to re-consider these fragments of the Italian Trecento through the prism of new research results.

"That scrap of painting on wood" (fig. 1) which was deemed worthy of "the hand of Giotto" at the time of its acquisition for the collection of Bishop Strossmayer in Rome in 1867, ${ }^{2}$ is a work from the circle of Bernardo Daddi (1280-1348), leading Florentine painter of his generation. ${ }^{6}$ Various versions of attribution noted down in the fortuna critica of the fragment held in Zagreb, which has been continuously displayed as part of the Gallery's permanent collection from its opening in 1884 and thus has always been well known to researchers, record the changes in defining the work of Bernardo

\footnotetext{
${ }^{5}$ Letter by Nikola Voršak to Josip Juraj Strossmayer, Rome, 24 ${ }^{\text {th }}$ March 1867, Archive of the Croatian Academy of Arts and Sciences, XI A / Vor. Ni. 11.

${ }^{6}$ More on the painter in: E. N. LUSANNA, Daddi, Bernardo, in Grove Art Online [January 2011].
} 
Daddi. ${ }^{7}$ A wider understanding and reception of Daddi's work, and works of the painters from his circle, has been given in a vivid historiography of the Zagreb painting's pendant, the right hand fragment of the same Crucifixion (fig. 2), whose different fortune specifically completes the fortuna critica of the Zagreb fragment. After continuous changes in ownership resulted in the loss of information on the painting's whereabouts, leading to its insertion into a group of so-called 'homeless paintings', 8 this fragment found its home at the Staatsgalerie in Stuttgart. It had been acquired for the Stuttgart Gallery not long after it had been exhibited in 1965 at the Wildenstein Gallery in London, as part of The Art of Painting in Florence and Siena from 1250 to 1500 exhibition, deemed by contemporaries as "something of a milestone in the history of art appreciation". "In the Editorial of The Burlington Magazine it is explained that "it was assumed the subject had been dealt with once and for all during the heyday of connoisseurship between 1880 and 1930. It was thought that scholars had little more to learn, and that, as far as the public was concerned, taste had changed and interest could no longer be whipped up in schools of painting where tradition stifled selfexpression. The assumption is of course absurd. [...] the joy of seeing gathered together a selection of works of this age and place is inexhaustible, and in any case every generation sees something new in everything in the past".$^{10}$

Thanks to the upheavals on the art market, among other things, and the growing dynamics of exhibition production, 'new' paintings, as well as fragments of altarpieces along with suggestions for their reconstruction continue to emerge. So it came that a fragment of a predella showing the Martyrdom of Saint Lawrence

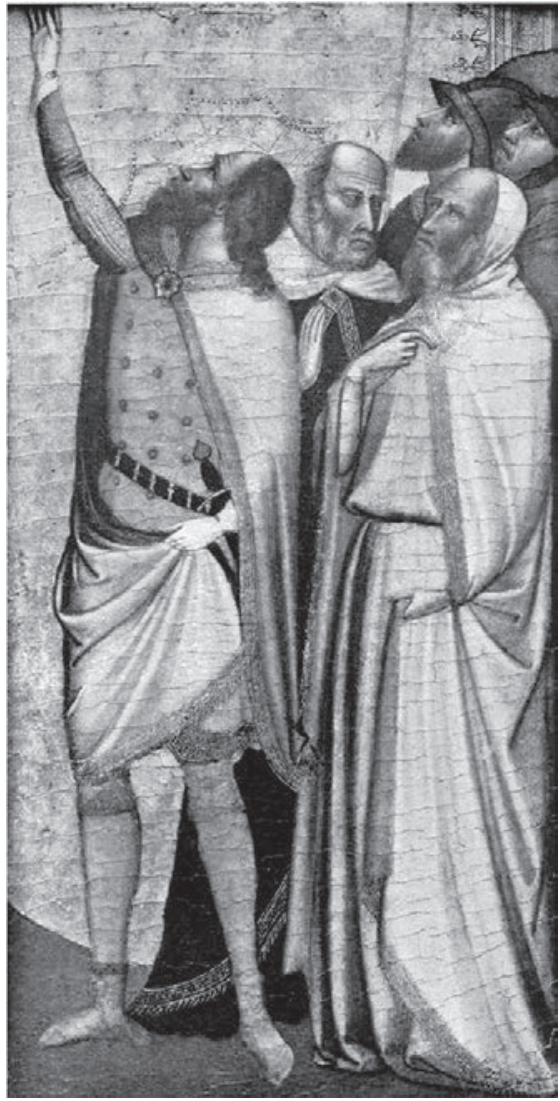

Fig. 2. Circle of Bernardo Daddi, Crucifixion (fragment), tempera on panel, 34,2 $\times 18 \mathrm{~cm}$, Staatsgalerie Stuttgart, inv. no. 3064 (Berenson 1963, p. 168, n. 7) emerged in 1995 on the art market, leading Miklòs Boskovits to identify it as the work of Niccolò di Pietro Gerini (active 1366-1414/15) ${ }^{11}$ and to propose that the painting used to be part of a predella alongside the Adoration of the Magi from the Berlin Gemäldegalerie. ${ }^{12}$ In 2005, the Berlin fragment

\footnotetext{
${ }^{7}$ Bernard Berenson listed the painting among the works of Bernardo Daddi (B. BERENSON, Italian Pictures of the Renaissance, Oxford, 1932, p. 164; B. BERENSON, Pitture italiane del Rinascimento, Milano, 1936, p. 145; B. BERENSON, Italian pictures of the Renaissance. Florentine School, London, 1963, p. 58). Richard Offner cites the Zagreb fragment in 1933 as the work of a painter then named "Amico di Daddi" (R. OFFNER, The Mostra del Tesoro di Firenze Sacra I, in The Burlington Magazine 63, 1933, p. 72-84), and in 1958 as a painting resembling the work of the Maestro di San Martino alla Palma (R. OFFNER, A Critical and Historical Corpus of Florentine Painting - The Fourteenth Century, Section III, Volume III, New York, London, 1958, p. 87). Miklòs Boskovits considers the painting a work by Daddi's workshop (M. BOSKOVITS, The Fourteenth Century. The Painters of the Miniaturist Tendency, Firenca, 1984, p. 67), while Sanja Cvetnić assigns it to Bernardo Daddi's close follower (S. CVETNIĆ, Tri atributivna problema srednjotalijanskog slikarstva u Strossmayerovoj galeriji u Zagrebu: Daddi, Lo Spagna i Cigoli [Three Problems of Attribution, Paintings From Central Italy at the Strossmayer Gallery in Zagreb, Daddi, Lo Spagna and Cigoli], in Radovi Instituta za povijest umjetnosti 21 , Zagreb, 1997, p. 69-77).

${ }^{8}$ B. BERENSON, 1963, op. cit., p. 168 (n. 7).

${ }^{9}$ Editorial. The Early Renaissance in Tuscany, in The Burlington Magazine 744, London, 1965, p. 109-110.

${ }^{10}$ Ibidem.

${ }^{11}$ More on the painter: D. GORDON, Niccolo di Pietro Gerini, in Grove Art Online [January 2011].

${ }^{12}$ M. BOSKOVITS, Frühe italienische Malerei: Gemäldegalerie Berlin, Berlin, 1998, p. 142-144.
} 


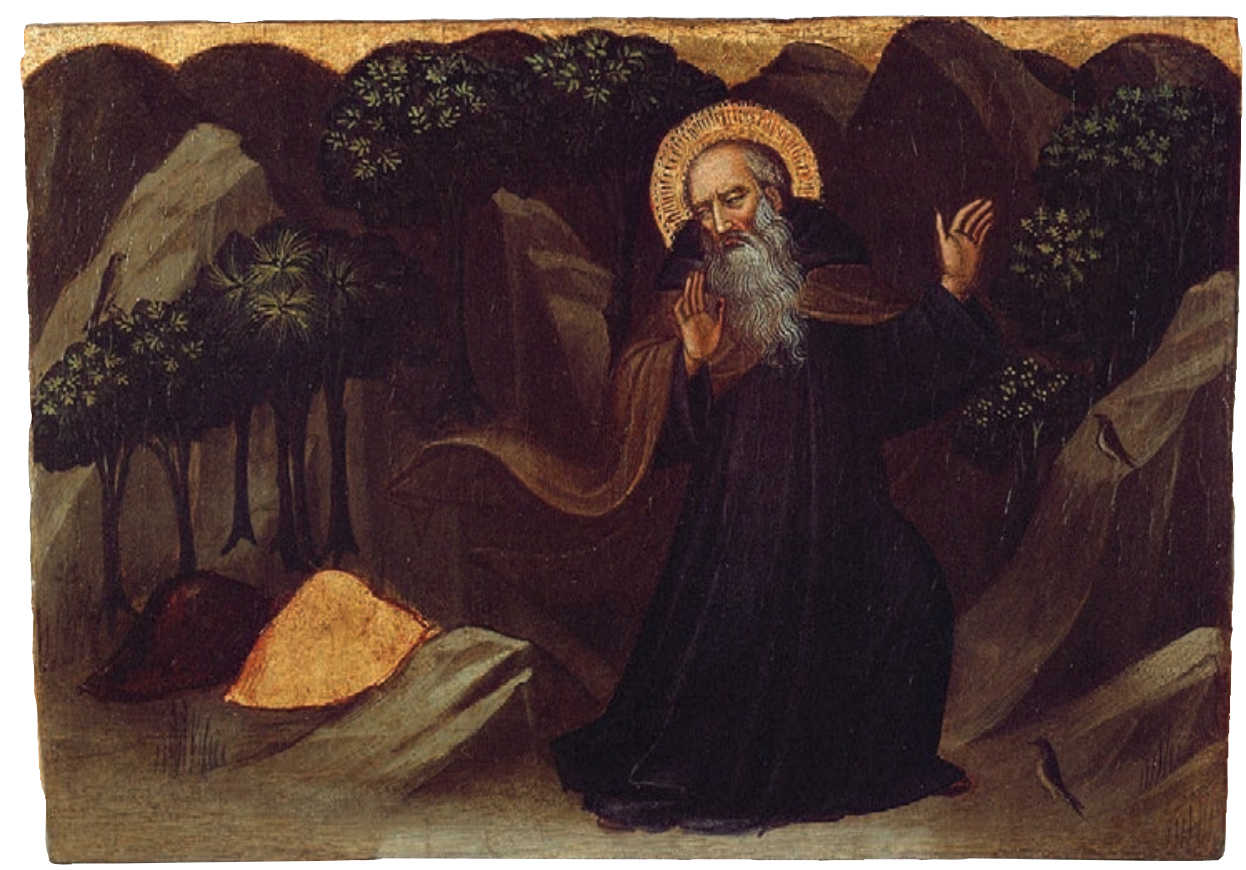

Fig. 3. Niccolò di Pietro Gerini, Temptation of Saint Anthony the Abbot, tempera on panel, $22 \times 32 \mathrm{~cm}$, The Strossmayer Gallery of Old Masters HAZU, inv. no. SG-28.

was proposed to be part of a predella along with the Temptation of Saint Anthony the Abbot from the Strossmayer Gallery in Zagreb, acquired by Bishop Strossmayer in Italy in or before $1875 .{ }^{13}$ (fig. 3). Boskovits' suggestion was accepted at the exhibition Geschichten auf Gold in Berlin in 2005, where a reconstruction proposal for the predella was expanded to include the fragment of the Beheading of Saint John the Baptist. ${ }^{14}$ Meanwhile, the inclusion of the Zagreb painting into the same context was confirmed in 2010 in the catalogue Italian Paintings from the Richard L. Feigen Collection, where the fragment Martyrdom of Saint Lawrence now belongs. ${ }^{15}$ All four dislocated fragments show clear similarities to one another: the figures are depicted in full height, the extant of pictorial space is limited by either a high placed landscape or an architectural segment, the halos are equally ornamented, and the facial hair of older figures are very similarly depicted, with parallel brush strokes, which became evident in the Zagreb painting upon the removal of the old retouches during the most recent restoration.

Furthermore, author of the Feigen Collection catalogue, Laurence Kanter, made a hypothesis on the identification of the altarpiece for which the reconstructed predella is likely to have been painted with the only known Gerini's polyptych that includes the saints whose lives are told on the predella fragments, from left to right: Saint Anthony the Abbot, Saint John the Baptist, the Madonna and Child in the central field to which the fragment of the Adoration corresponds, and Saint Lawrence. ${ }^{16}$ The scene on the missing predella fragment below Saint Julian depicted on the last panel on the right is most probably set in the landscape, considering the regular alteration of spatial scenes setting on the predella.

\footnotetext{
${ }^{13}$ LJ. DULIBIĆ, Talijanske slike..., op. cit. (n. 1); LJ. DULIBIĆ, Predela..., op. cit. (n. 3). See also I. PASINI TRŽEC, LJ. DULIBIĆ, Slike starih majstora u Strossmaverovoj zbirci nabavljene posredstvom kanonika Nikole Voršaka u razdoblju od 1869. do 1880. [Paintings by Old Masters in Strossmayer's Collection, Acquired through Canon Nikola Voršak between 1869 and 1880], in Radovi Instituta za povijest umjetnosti 35, Zagreb, 2011, p. 207-220, 219.

${ }^{14}$ R. F. LACHER, "Niccolò di Pietro Gerini, Mittelstück der Predella eines unbekannten Retables, um 1395", in Geschichten auf Gold. Bilderzählungen in der frühen italienischen Malerei, S. WEPPELMANN (ed.), Berlin, 2005, p. 151-155. The beheading of Saint John the Baptist is a 'homeless painting', known through a photograph by Giordano Bombelli.

${ }^{15}$ L. KANTER, op. cit. (n. 3).

${ }^{16}$ Polyptych no. 8610 at the Galleria dell'Accademia in Florence. Ibidem, p. 38, fig. 4.
} 
The polyptych was painted originally for the Florentine church of San Benedetto fuori Porta a Pinti, built in January 1400 as a daughter church of the Camaldolese Order. It is dated by inscription in the year 1404, nearly ten years after the fragments have been previously dated. This shift in dating the predella fragments can be indirectly confirmed by the iconography of the Zagreb fragment, as the scene depicting Saint Anthony the Abbot avoiding the gold as if it were fire seems to have only been familiar in painterly tradition since the early 1400 s. ${ }^{17}$ Henceforth, the reconstruction proposal not only brings together an entire sequence of dislocated fragments found in different museums and private collections around the world, but also serves as "a benchmark for recognizing Gerini's late style in small-scale narrative paintings" ${ }^{18}$ with the painterly tradition of the Trecento extending into the Quattrocento.

Yet another painting at the Strossmayer Gallery, Saint Nicholas with Donors and Angels (fig. 4), throws some light on Florentine painting at the end of the Trecento. It found its way into the Gallery's collection after World War II as part of a donation of Ante Topić Mimara. ${ }^{19}$ At the Gallery, the painting was attributed as the work of Giovanni da Milano; ${ }^{20}$ however, its identification with a reproduction of a 'homeless' painting assembled in the group of several paintings which form the core of the opus of so-called Maestro di San Martino a Mensola ${ }^{21}$ brings us not only to the correction of its attribution but to discovery of a specific double historiography of the painting. ${ }^{22}$

In 1959, Brigitte Klesse has named the anonymous painter Maestro di San Martino a Mensola, active in Florence in the last two decades of the 14th century, after the provenance of the triptych Madonna and Child with Eight Saints and a Patron at the church San

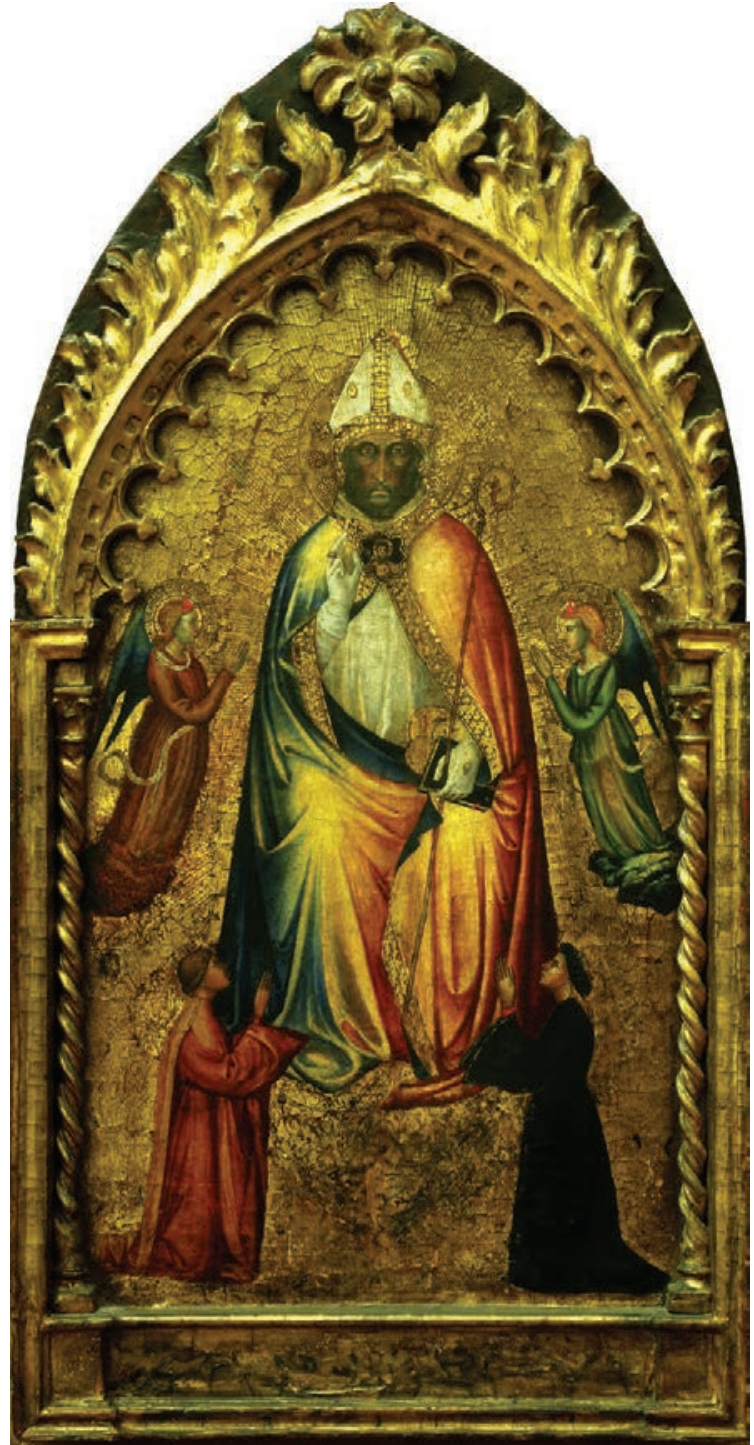

Fig. 4. Maestro di San Martino a Mensola, Saint Nicholas with Donors and Angels, tempera on panel, 103,2 $\times$ 52,4 cm, The Strossmayer Gallery of Old Masters HAZU, inv. no. SG-494.

\footnotetext{
${ }^{17}$ Cfr. C. WILSON, Fra Angelico: new light on a lost work, in The Burlington Magazine 1112, London, 1995, p. 737-740, n. 7. ${ }^{18}$ L. KANTER, op. cit., p. 38 (n. 3).

${ }^{19}$ LJ. GAŠPAROVIĆ, V. ZLAMALIK, Izložba odabranih djela iz zbirke Ante Topić Mimara [Exhibition of selected works from the collection of Ante Topić Mimara], Zagreb, [196-?]

${ }^{20}$ V. ZLAMALIK, Jedan mogući Giovanni da Milano u Strossmaverovoj galeriji [One plausible Giovanni da Milano at the Strossmayer Gallery], in Peristil 12-13, Zagreb, 1969-70, p. 53-58; V. ZLAMALIK, Strossmaverova galerija starih majstora Hrvatske akademije znanosti i umjetnosti [The Croatian Academy of Arts and Sciences' Strossmayer Gallery of Old Masters], Zagreb, 1982, Cat. No. 3, p. 30-31.
}

${ }^{21}$ B. KLESSE, Der Meister des Hochaltars von S. Martino a Mensola, in Mitteilungen des Kunsthistorischen Institutes in Florenz 8, Florence, 1959, p. 247-252, 250; R. FREMANTLE, Some additions to a late Trecento Florentine: The Master of San Martino a Mensola, in Antichità Viva, 12, Florence, 1973, p. 3-13, 6; R. FREMANTLE, Florentine Gothic Painters from Giotto to Masaccio - A Guide to Painting in and near Florence 1300 to 1450, London, 1975, p. 284.

${ }^{22}$ Lj. DULIBIĆ, Talijanske slike 14. stoljéca... op. cit. (n. 1). 


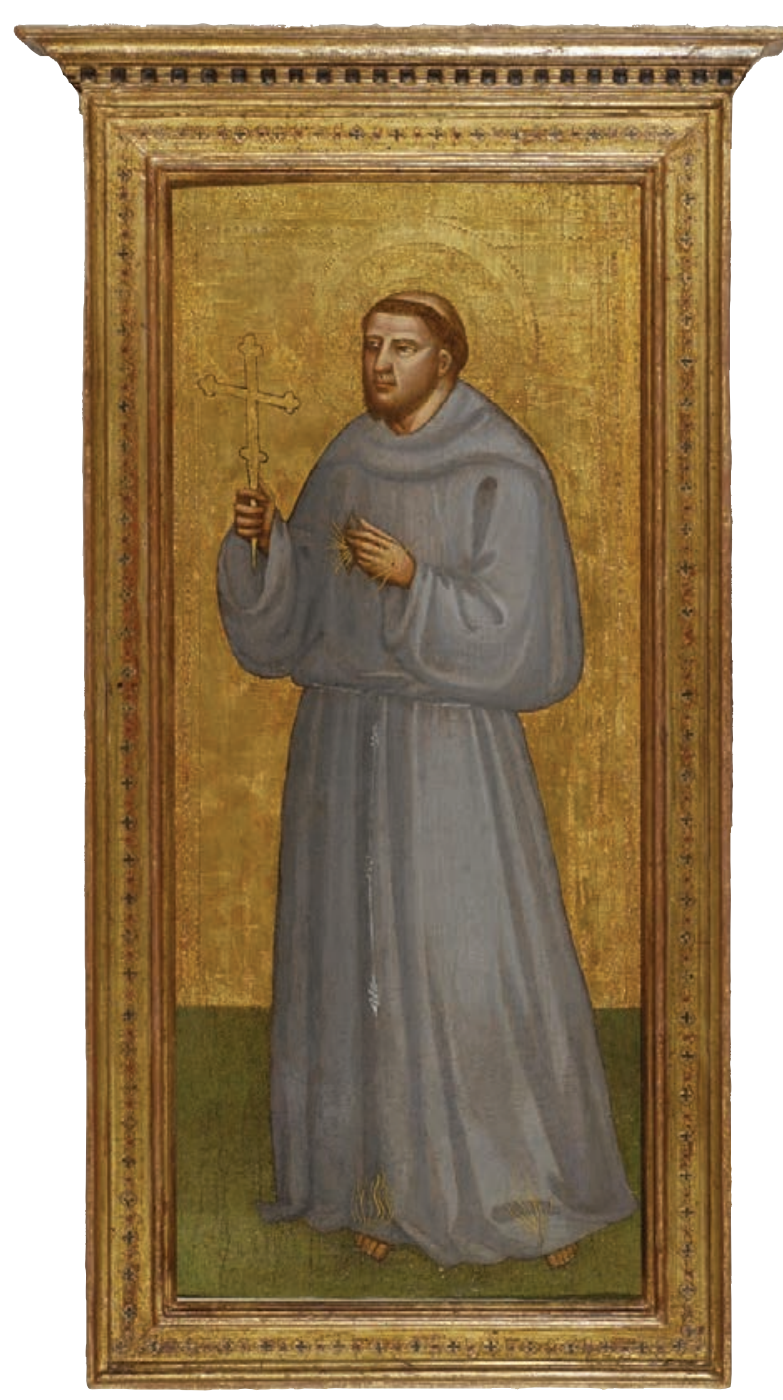

Fig. 5. Lorenzo di Bicci, Saint Francis of Assisi, tempera on panel, 62,5 $\times 26,8 \mathrm{~cm}$, The Strossmayer Gallery of Old Masters HAZU, inv. no. SG-685.
Martino a Mensola near Settignano. ${ }^{23}$ The works assembled around this triptych, dated in 1391, set off analogous characteristics of style such as a strong negation of spatial values, flat, sharp and angular forms, elongated figures, and dark colours. Klesse's catalogue has gradually been expanded by Luciano Bellosi (who identified the painter as Francesco di Michele), ${ }^{24}$ Federico Zeri, Richard Fremantle and Miklòs Boskovits, all the while leaving the Zagreb painting within the core of painter's opus. ${ }^{25}$

Reconstruction of the historiography of the Zagreb painting brought to light the information on its earlier provenance: in the year 1927, the painting had been in the ownership of a then leading German art dealer firm, Julius Böhler Kunsthandlung in Munich. ${ }^{26}$ Using this information as the basis for further research, we found a photograph of the painting in the Berenson's Homeless Paintings of the Italian Renaissance. ${ }^{27}$ On the basis of an inventory number noted on the back of the photograph it was plausible to find the painting in the Inventory of the Julius Böhler Kunsthandlung: it had been purchased on 26th June 1926 from R. Zinser in Stuttgart for 2000 Marks as "Tomaso da Modena", and later sold on 20th December 1946 to Richard Billinger in Starnberg for 5000 Marks as "Spitzbogenbild umbrisch". ${ }^{28}$ Hence, we can conclude that the painting's 1926 seller was dealer Richard H. Zinser (around 1883-1983) from Stuttgart, who later in his career specialized in prints and

\footnotetext{
${ }^{23}$ Cfr. B. KLESSE, op. cit., p. 247-252 (n. 21).

${ }^{24}$ Cfr. L. BELLOSI, Francesco di Michelle, Il Maestro di San Martino a Mensola, in Paragone Arte 419-421-423, Florence, 1985, p. 57-63. See also A. LADIES, "The Reflective Memory of a Late Trecento Painter: Speculations on the Origins and Development of the Master of San Martino a Mensola", in Studies in Italian Art, London, 2001, p. 165-182; E. S. SKAUG, Did Francesco di Michele, alias the Master of San Martino a Mensola, start out in Giovanni Bonsi's workshop?, in Arte Christiana 97, 855, Milano, 2009, p. 403-408; A. SGARRELLA, Una tavola francescana per le terziare dello spedale di San Paolo a Firenze, in Mitteilungen des Kunsthistorischen Institutes in Florenz 54, 3, Florence, 2010-2012, p. 521-529.

${ }^{25}$ See also L. BELLOSI, Da Spinello Aretino a Lorenzo Monaco, in Paragone Arte 187, Florence, 1965, p. 18-43, 19; F. ZERI, Sul catalogo dei dipinti toscani del secolo XIV nelle Gallerie di Firenze, in Gazette des Beaux-Arts 71, Paris, 1968, p. 76; R. FREMANTLE, Some additions... op. cit., p. 3-13 (n. 21); R. FREMANTLE, Florentine Gothic Painters... op cit., p. 257-284 (n. 21); M. BOSKOVITS, Pittura fiorentina alla vigilia del Rinascimento, Florence, 1975, p. 124-125, 379-381.

${ }^{26}$ Klesse states that the painting had been owned by Julius Böhler in 1927: B. KLESSE, op. cit., p. 250 (n. 21), Fremantle gives thanks to Julius Böhler on the painting's photograph he had sent him: R. FREMANTLE, Some additions... op. cit., p. 6 (n. 21).

${ }^{27}$ Biblioteca Berenson, Fototeca, Villa I Tatti - The Harvard University Center for Italian Renaissance Studies, n. 120030_1 i 120030_2 (verso).

${ }^{28}$ We hereby thank Dr Richard Winkler, Head of the Bayeriches Wirtschaftsarchiv, for this information.
} 
drawings, ${ }^{29}$ and its 1946 buyer was Richard Billinger (1890-1965), Austrian writer active in Munich. ${ }^{30}$ The painting had obviously not been in Billinger's possession for long, considering that Ante Topić Mimara included it in the photo album of his collection in $1948 .{ }^{31}$ Documented provenance of the painting during the turbulent years of the first half of the 20th century is a rare example among the paintings in Mimara's bequest, given that no documentation on individual paintings' provenances had ever been attached to the donation.

Neither any documentation on the provenance of particular paintings had been included into the last large donation of Old Master paintings to the Strossmayer Gallery, the bequest of Dragan Plamenac (1895-1983), renowned musicologist and composer. ${ }^{32}$ Plamenac acquired his collection of ten paintings at various auctions and antique stores throughout Italy and the Netherlands, in order to decorate his home in Urbana, USA. These paintings have only been included into the art history after their musealization and presentation at the exhibit of bequeathed artworks in $1986 .{ }^{33}$

The painting of Saint Francis (fig. 5) has been included into the permanent collection of the Strossmayer Gallery only in 2013, upon recent restoration. Miklòs Boskovits suggested the attribution to Lorenzo di Bicci, ${ }^{34}$ a Florentine painter from the second half of the $14^{\text {th }}$ century and forefather of the family workshop that dominated the Florentine art production for more than a century - he was succeeded by his son Bicci di Lorenzo and later by his grandson Neri di Bicci. ${ }^{35}$ Lorenzo di Bicci had been included by Vasari into his compendium of famous artists; however, he listed the biography of his son Bicci under Lorenzo's name. ${ }^{36}$ Today, on the basis of stylistic similarities, over sixty paintings on panel and several frescos, executed from 1370 to 1410, are ascribed to him. ${ }^{37}$ In its impeccable technical execution, distinctive quality of colour values, the immovability of highly plastic figures, which almost appear as stone blocks enveloped in drapery, placed in front of a golden background with no distinctly specified setting, Zagreb painting reveals all the peculiarities of Lorenzo's painterly style, confirming him as a significant representative of the traditional tendencies of Florentine painting of the time.

Far from being representative of all diversities of Trecento painterly style, this group of paintings which were obtained for the Strossmayer Gallery in different periods and under different circumstances, as well as fortuna critica and the fate of their counterparts, show the variety of ways in which not only rich historiography but also vivid afterlives of the works of art reflect the changes in the perception and the reception of Trecento painting in the second half of the $19^{\text {th }}$ Century and throughout the $20^{\text {th }}$ Century.

\footnotetext{
${ }^{29}$ More on Zinser in: B. M. ROSENTHAL, The gentle invasion: continental emigré booksellers of the thirties and forties and their impact on the antiquarian booktrade in the United States, lecture at Columbia University School of Library Service, 15th December 1986, available at: http://ihl.enssib.fr/the-gentle-invasion [December 2013]

${ }^{30}$ Richard Billinger (St. Marienkirchen bei Schärding, 1890. - Linz, 1965.), Austrian writer who, as a liberal artist living in Berlin, Munich and Starnberger See, was thought to have been the author of Blut-und-Boden literature, wrote plays, prose and film scenarios. Billinger, Richard dans Deutsche Biographische Enzyklopädie, Vol. 1, Munich 1999, p. 528-529. Despite his homosexuality, he was especially successful at the time of the NS-regime; at the Stifterhaus in Linz, on 14th October 2013, the exhibition Heimat. Körper. Kunst - Richard Billinger und seine Archive was opened.

${ }^{31}$ The Ante Mimara Collection of Artworks, 1948, album I/I-III, no. 10, Archive of the Strossmayer Gallery. More on these photo albums in: V. KUSIN, Mimara, Zagreb, 1987, p. 120.

${ }^{32}$ More on Plamenac in: J. ANDREIS, Plamenac, Dragan, dans Muzička enciklopedija, Vol. 3, Zagreb, 1977, p. 91-92.

${ }^{33}$ Cfr. V. ZLAMALIK, Dragan Plamenac, Izložba darovanih umjetnina [Exhibition of bequeethed works], Zagreb, 1986.

${ }^{34}$ The attribution suggestion was made by Boskovits during a conversation with Lj. Dulibić in Florence in 2003.

${ }_{35}$ More on the painter in: G. M. FACHECHI, Lorenzo di Bicci, dans Dizionario Biografico degli Italiani, Vol. 66, Rome, 2007, available at: http://www.treccani.it/enciclopedia/lorenzo-di-bicci_\%28Dizionario-Biografico\%29/ [November 2013]

${ }^{36}$ G. VASARI, Le vite, CORRADO RICCI (ed.), Milano, [1911?], p. 219-221.

${ }^{37}$ Boskovits compiled a catalogue of the works after Gronau. See also G. M. FACHECHI, op. cit. See also H. D. GRONAU, Lorenzo di Bicci. Ein Rekonstruktionsversuch, in Mitteilungen des Kunsthistorischen Instituts in Florenz 4, 2/3, Florence, 1933, p. 103-118.
} 


\section{PRILOG POZNAVANJU SLIKARSTVA TRECENTA U STROSSMAYEROVOJ GALERIJI}

Novija saznanja o nevelikoj ali istraživački poticajnoj grupi talijanskih slika iz 14. st. u Strossmayerovoj galeriji, temeljena ponajviše na kritičkom uvidu u literaturu, predstavljena su na Danima Cvita Fiskovića 2005. U međuvremenu su dvije od tih slika restaurirane, prijedlog djelomične rekonstrukcije cjeline kojoj je jedna od njih nekada pripadala razložen je u pojedinačnoj studiji te potvrđen u kasnijoj literaturi, a istraživanje tada prezentiranih slika nastavlja se uz oslonac na nove metodološke aspekte. Kroz prizmu novih istraživanja, u čast Igora Fiskovića sada ponovno objedinjujemo četiri slike talijanskog trecenta koje su u različito vrijeme i pod različitim okolnostima prispjele u Strossmayerovu galeriju.

Biskup Strossmayer kupio je u Italiji u 2. pol. 19. st. lijevi fragment malenoga Raspeća iz kruga Bernarda Daddija i fragment predele Nicolòa di Pietro Gerinija Sveti Antun Pustinjak. Te su nabavke izraz rastućeg interesa sakupljača 19. st. za rano talijansko slikarstvo, o čijoj daljnjoj recepciji tijekom 20. st. svjedoči sudbina ostalih fragmenata nekada pripadajućih istim cjelinama. Desni je dio Raspeća, nakon učestalih promjena vlasništva koje su uzrokovale gubitak podataka o smještaju i uključenje u skupinu tzv. 'homeless paintings', muzealiziran u Staatsgalerie Stuttgart nakon izložbe toskanskog slikarstva 1250.-1500. u Londonu 1965., kojom je otklonjena ranija pretpostavka da je tema iscrpljena nakon što je u razdoblju od 1880. do 1930. dosegla vrhunac. Zahvaljujući sve dinamičnijoj izložbenoj produkciji i zbivanjima na tržištu umjetnina 'nove' se slike, odnosno fragmenti i prijedlozi rekonstrukcije nekadašnjih cjelina, i dalje pojavljuju. Tako su uz zagrebački danas poznata još tri fragmenta Gerinijeve predele, a iznesena je i pretpostavka o identifikaciji oltarne slike kojoj je predela nekoć pripadala, čime je datacija fragmenata predele pomaknuta u 1404. godinu, što posredno možemo potvrditi ikonografskim sadržajem zagrebačkog fragmenta.

Slika Sveti Nikola s donatorima i andelima Maestra di San Martino a Mensola prispjela je u zbirku nakon II. svjetskog rata kao dio donacije Ante Topića Mimare. Njenom identifikacijom sa slikom višekratno reproduciranom uz napomenu "smještaj nepoznat" razotkrivena je specifična dvostruka historiografija slike, što je iznijelo i podatak o ranijoj provenijenciji: 1927. je bila u vlasništvu tada vodeće njemačke prodajne galerije odnosno aukcijske kuće Julius Böhler u Münchenu. Među Berensonovim Homeless Paintings pronašle smo fotografiju slike na čijoj je poleđini zabilježen broj preko kojega je bilo moguće identificirati sliku u inventaru tvrtke Julius Böhler i iščitati imena nekadašnjih vlasnika, na temelju čega utvrđujemo da je prodavatelj slike 1926. bio štutgartski diler Richard $\mathrm{H}$. Zinser, a njezin kupac 1946. austrijski pisac djelatan u Münchenu, Richard Billinger, u čijem se vlasništvu slika kratko nalazila, budući da ju je Mimara 1948. uvrstio u fotoalbum svoje zbirke. Utvrđena provenijencija ove slike tijekom turbulentnih godina 20. st. predstavlja rijedak takav primjer $u$ Mimarinoj donaciji, budući da donator nije ustupio dokumentaciju o podrijetlu umjetnina.

Posljednja veća donacija slika starih majstora Strossmayerovoj galeriji ostavština je muzikologa Dragana Plamenca, sastavljena od deset slika koje je Plamenac nabavio na talijanskom i nizozemskom tržištu kako bi ukrasio prostorije svoga doma u Urbani, SAD. Te su se slike počele uključivati u povijesno-umjetnički imaginarij nakon muzealizacije 1986. Slika Sveti Franjo, s atribucijom Lorenzu di Bicciju koju je predložio Miklòs Boskovits, nedavno je restaurirana te je uključena u stalni postav Galerije 2013.

lako je riječ o uistinu nevelikoj grupi od svega četiri slike ovdje prezentirani rezultati istraživanja pokazuju u kolikoj se mjeri u živoj i bogatoj historiografiji i sudbini nekolicine umjetničkih djela ogledaju mijene u recepciji slikarstva trecenta.

Ključne riječi: Strossmayerova galerija starih majstora HAZU, talijansko slikarstvo trecenta, Bernardo Daddi, Niccolo di Pietro Gerini, Maestro di San Martino a Mensola, Lorenzo di Bicci, aukcijska kuća Julius Böhler, istraživanje provenijencije, povijest sakupljanja 